\title{
Bioecology and Uses of Desert Truffles (Pezizales) in the Middle East
}

\author{
Mustafa Nadhim OWAID ${ }^{1,2}$ \\ ${ }^{I}$ Department of Heet Education, General Directorate of Education in Anbar, Ministry of Education, \\ Heet, Anbar 31007, Iraq \\ ${ }^{2}$ Department of Ecology, College of Applied Sciences, University of Anbar, Anbar, Iraq
}

(Corresponding author's e-mail: mustafanowaid@gmail.com)

Received: 19 September 2016, Revised: 18 February 2017, Accepted: 17 March 2017

\begin{abstract}
Desert truffles grow naturally after rainfall during the season of Al-Wasm in arid and semi-arid districts of Saudi Arabia, Iraq, Kuwait, Qatar, Bahrain, United Arab Emirates, Syria, Jordan, Palestine, Lebanon, Egypt, Iran, Turkey, Tunisia, Algeria, Libya, and Morocco. Al-Wasm provides rainfall of more than $200 \mathrm{ml}$ in September to October in the Arabian Peninsula, and is important for the early growth and appearance of desert truffles. The amount of truffles increases depending on the amount of rainfall, as in other countries. Two genera of desert truffles, Terfezia sp. and Tirmania sp., are the most abundant in the Middle East. Desert truffles have nutritional value due to their proteins, carbohydrates, fats, fibers, and low energy. Also, they have immune-modulating, hepatoprotective, antidepressant, antibacterial, antifungal, antiviral, antioxidant, and antiradical properties due to their content of phenol, carotenoid, anthocyanin, ascorbic acid, flavonoid, tannin, glycoside, ergosterol, etc. Hence, the introduction of desert truffles in the pharmacological field is important, especially in the treating of eye infections and cancer. Finally, the habitats of the truffles and the host-plants need protection as nature reserves.
\end{abstract}

Keywords: Ascomycetes, biomedical applications, Helianthemum sp., hypogeous fungi, tuber

\section{Introduction}

Truffles were mentioned in the ancient world by the Romans and Greeks, and many studies have taken place to obtain further information and data about several varieties of desert truffles from different locations [1]. Symbiotic truffles (Tuber sp.) develop underground and are related to host-plant roots of the family Cistaceae, especially the genus Helianthemum [2]. The term "desert truffles" is used to refer to edible hypogeous macrofungi, which grow in arid zones of the Mediterranean. Occasionally, some truffle genera found in semi-arid zones, such as Terfezia, Tirmania, Tuber, Picoa, Delastria, and Loculotuber [3]. Many studies have produced desert truffles in the laboratory, such as in Iraq [4], Iran [5,6], Kuwait, Tunisia [7] and Saudi Arabia [8].

In the Arabian region, the common name of the desert truffle is "al-fag'a", but the classic Arabic word is "al-kamah', or "kame". Most desert truffles collected from the Arabian Desert belong to 2 genera, Terfezia sp. and Tirmania sp. [9]. Tirmania nivea (white-colored) is called "zubadi" or "zubaidi" as a common name in some Arabian countries. It has been found to be the most preferred expensive and common type of desert truffle in this region by both groups of respondents because of its good light smell, delicacy, and soft white tissues. Commonly, the second group is including Terfezia boudieri (black-colored) and Terfezia claveryi (brown-colored), "ikhlasi" or "kholasi" [9-11]. The truffles are pale sandy brown, grey or white in color, irregularly spherical, with a slightly spongy texture, with sizes from $1-7 \mathrm{~cm}$, without a particular smell [1]. The species of a desert truffle can be identified using morphological and microscopical properties and/or genetic analyses [12]. Also, each ascus of Terfezia boudieri contains 8 ascospores [13]. Black truffles are highly appreciated worldwide because of their 
http://wjst.wu.ac.th

special taste and nice smell [14]. Eastern Turkey also has truffle species, which appear in the local markets of Gaziantep; it has a price around 320 pence a kilo [1]. Wild edible truffles and fungi are collected from the soil environment for feeding and to gain money in more than 80 countries [13] like Iraq which had a reached a high price of $52 \mathrm{USD} / \mathrm{kg}(65,000 \mathrm{IQD} / \mathrm{kg})$, according to the amount in the local market [4]. Some problems occur in markets, such as spoilage of truffles, since the whole stock is sold as soon as it is collected. Aspergillus sp., Mucor sp., Bacillus species, and E. coli, found on the outer and inner parts of Terfezia boudieri, Tirmania nivea, and Tirmania pinoyi, causes spoilage of truffles [15]. Because of the lack of data about the use and biomedical applications of desert truffles, this review is written in order to increase the attention of scientific community towards its useful application.

\section{Ecology and distribution}

The gathering of desert truffles (Pezizales) is a widely practised activity in Saudi Arabia during offroad driving, leading to increased habitat damage. Restrictions on the time and methods of harvesting are needed to ensure that the activities remain sustainable [16]; thus, truffles and their host-plant need to be protected from animal pasture and agriculture, by turning those fields into natural protected areas [17]. Desert truffles are found in arid and semi-arid zones in Saudi Arabia [8], Iraq [4], Kuwait, United Arab Emirates [1], Qatar [18], Bahrain [10], Syria, Palestine, Lebanon, Jordan, Egypt [19], Iran [13,20], Turkey [17], Tunisia [21], Algeria [22], Libya [19], and Morocco [3].

Generally, desert truffles appear in limited seasons. Desert truffles develop underground in arid deserts [1]. In some regions of Bahrain, 3 species of desert truffles have been identified [10]. Also, Terfezia boudieri has been collected from some districts of southern Tunisia [21]. Usually, desert truffles have a symbiotic relationship with the host-plant; thus, truffles are found close to the roots of the hostplant Helianthemum sp. (family: Cistaceae) [1]. Studies agree that heavy rains of more than $200 \mathrm{~mm}$, in mild to warm weather, locally recognized as "Al-Wasm", followed by heavy evening or early morning dewfalls, are optimal conditions for growth of desert truffles. Both thunder and lightning are considered essential requirements for truffle formation [10].

In Iraq, the Anbar desert is rich with desert truffles [4,11] such as Tirmania sp., which appear in Figure 1. In Saudi Arabia, desert truffles from the eastern provinces are recorded as being black, white, and reddish in color. They appear in local markets in November to December, dependent on rainfall amount, as in the other produced countries [1]. In Iran, desert truffles are particularly harvested during mid-winter and early spring (January to March) [13]. In Kuwaiti markets, it appears from November to January in each season, dependent on the progression of each season [1].

In Turkey, Terfezia boudieri appears from March to May [17]. In Iran, several species of desert truffle can be found growing in the zones of the Zanjan, Qazvin, Bandar-e Abbas, and Tabriz provinces [13]. However, in Algeria, total and specific productivities (Terfezia arenaria, Terfezia claveryi, and Tirmania nivea) are closely positively related to autumnal precipitation occurring during October to December. The productivity of desert truffles was found under the hyper-arid climatic conditions of the desert in Algeria [22]. Wet autumn favored a heavy yield and, conversely, dry autumn induced a scarcity of truffles, which have high prices as they are highly esteemed. An additional help is the fact that the growth of the truffle fruit body often causes cracking of the ground surface. It is worth stating that the Kuwait desert is a relatively flat sand and gravel plain, with few dunes [1].

In Algeria, desert truffles grow in heterogeneous soils of the sandy texture, moderately calcareous $(10.19 \%)$, slightly alkaline (7.87), with low organic matter $(0.86 \%)$ and slight phosphorus content [23]. In Turkey, truffle-producing soil for Terfezia boudieri is sand-clay and limey (54.73\% sand, 21.97 clay, $23.30 \%$ dust, $3.78 \%$ lime, and $1.85 \%$ organic matter), with a $\mathrm{pH}$ of 7.12 and nitrogen content of $0.12 \%$ [17]. However, some truffles are found in acidic soil, such as Terfezia arenaria and Terfezia fanfani. Terfezia claveryi, Terfezia boudieri, and Terfezia olbiensis grow in basic soil [3]. Both strains of $T$. claveryi and Picoa lefebvrei exhibit a growth mycelia-like as in drought-tolerant fungi. The increased alkaline phosphatase activity can be seen in both truffles in moderate water stress and drought conditions because of the functional adaptation of truffle mycelia. Thus, alkaline phosphatase activity can be used as an indicator of the metabolic activity of this fungus [24]. 
http://wjst.wu.ac.th

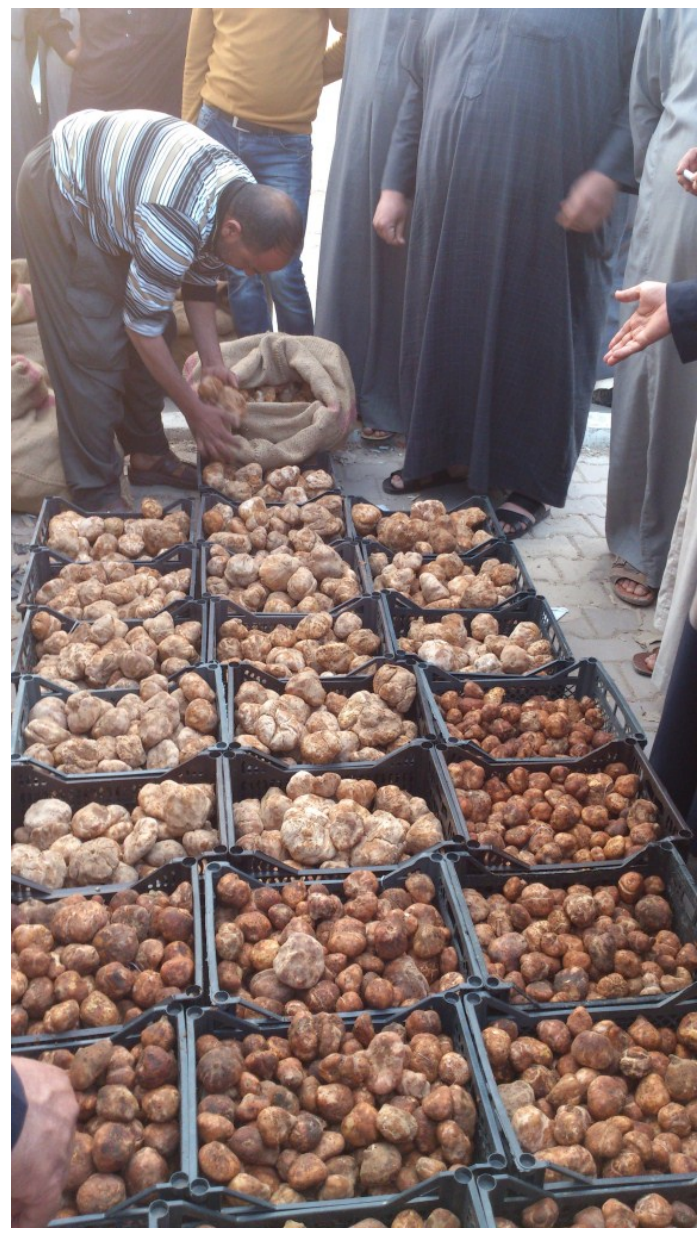

Figure 1 Desert truffles (Tirmania sp.) in the main market of Heet (Hit) district, Anbar, Iraq, in February 2014 by Owaid [4].

\section{The mycorrhizal association of desert truffles}

The hypogeous ascomycetes Terfezia sp. and Tirmania sp. live in mycorrhizal association with Helianthemum lippii (Cistaceae) [22], as seen in Figure 2. Moreover, P. lefebvrei could be a good truffle candidate for future desert truffle mycorrhizal plant cultivation programs in semi-arid Mediterranean areas [24]. Terfezia boudieri occurs infrequently and associates with the plant-host Helianthemum salicifolium [17], and Picoa lefebvrei and Picoa juniper with H. salicifolium [25]. Some desert truffles are found in the rhizosphere soil of Helianthemum lippii, higher than in soil without a host-plant [26,27].

Picoa sp. lives in symbiosis with $H$. lippii, such as in Kuwait. It is not a true truffle and is a popular fresh food, which appears after early rains. The one recipe available is highly flavored and spiced, in a similar manner to an Oman recipe. Sizes up to $10 \mathrm{~cm}$ are quoted [1]. The development of truffles is closely linked with high rainfall, which occurs at the start of winter. The desert truffles colonize desert depressions since geomorphological zones accumulate rainwater which promotes the growth of both truffles and their host-plants [22].

Moreover, stress induces a change in the mycorrhizal type formed, which is more intracellular under conditions of drought stress for $H$. almeriense with Terfezia claveryi [28]. Navarro-Rodenas et al. [29] suggested that the ascocarp of $T$. claveryi may, at some development stages, become independent on 
http://wjst.wu.ac.th

nutrition from the host plant. In vitro, Lopez-Nicolas et al. [30] confirmed the ability of the compound $\beta$ cyclodextrin to stimulate the mycelial growth of $T$. claveryi. Slama et al. [7] succeeded in the cultivation of Terfezia boudieri in the field, using the mycorrhizal plant of Helianthemum sessiliflorum in gypsy and sandy loam soils after one year.

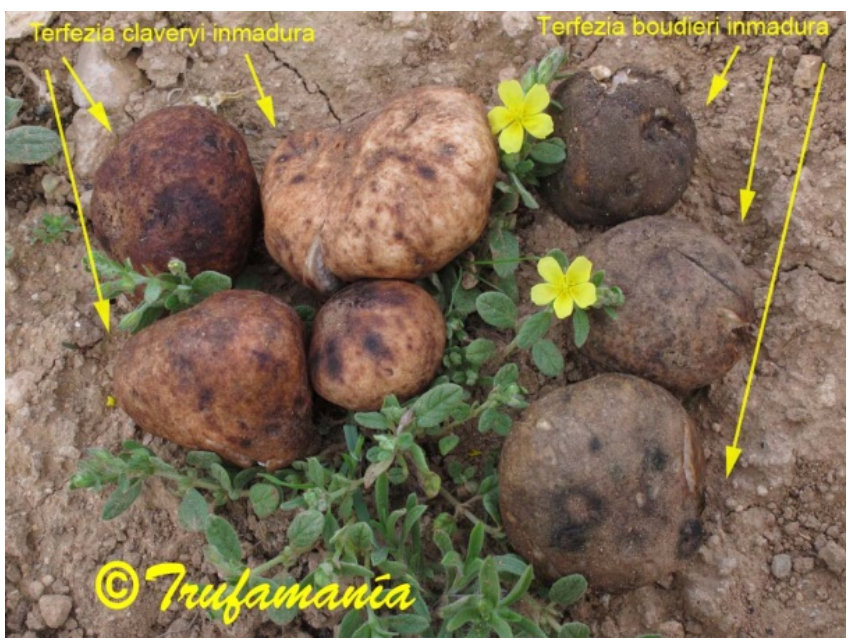

Figure 2 Terfezia sp. in mycorrhizal association with Helianthemum sp. (Cistaceae) [3].

\section{Classification}

The name "tuber' is the scientific name for a family of underground macro-fungi, approximately classified as truffles or desert truffles. Desert truffles are distributed in arid and semi-arid areas around zones of the Mediterranean and the Middle East [1]. Table 1 shows the most common species found in the Middle East and the Mediterranean region, according to many studies. From 2 families, about 5 genera (Terfezia sp., Tirmania sp., Tuber sp., Picoa sp., and Phaeangium sp.) and 28 species of desert truffles have been recorded in these zones as common truffles. Desert truffles were known by the Romans and called "tuber", which in Latin means "hump" or "bulge", as they do in the ground when mature, and concern "true truffles". Other truffle species were discovered later. Nowadays, "desert truffle" is a term used for all hypogeous fungi. Desert truffles called "fuga" in Arabic, which is from the first sight of desert truffles on the ground [1].

Also, white truffle is famous and is called "terfez" as a common name, a derivative from its scientific name [1]. In Morocco, its common name is "terfass", "terfess" or "terfez" [3]. Desert truffles (Terfezia sp.) are also found in the United Arab Emirates. The Turkish name is "keme", derived from the Arabic. In Turkey, some truffles are found, such as Tuber micheli and T. brumale [1].

Desert truffles belong to the order Pezizales (Ascomycetes), but formerly belong to the order Tuberales; the Pezizaceae family (Terfezia, Tirmania, Peziza, Pachyphloeus, Mattirolomyces, Cazia, Kaliharituber, Eremiomyces, Hydnotryopsis, Ruhlandiella, Stephensia, and Amylascus) and the Tuberaceae family (Tuber, Phaeangium, Picoa, Choiromyces, Dingleya, Labyrinthomyces, and Reddellomyces) [19,20,27,31]. Terfezia sp. and Tirmania sp. belong to Pezizaceae and Tuber sp. to Tuberaceae [31]. Also, other species of truffles include Terfezia claveryi, T. arenaria, T. oligosperma, Tirmania africana, Tuber nitidum, and Tuber asa [32]. Generally, Terfezia sp. disappeared in some deserts like Desert of North America [33]. But from a genetic point of view, Terfezia claveryi Chatin 1891 is equal to T. hafizi Chatin 1892 [34]. A close genetic relationship between Tirmania sp. and Terfezia sp. has been reported. They may develop a hypogeous habit as an adaptation to heat and drought in Middle Eastern ecosystems [35]. 
http://wjst.wu.ac.th

Table 1 Some species of desert truffles, order Pezizales [19,20,27,31-35].

\begin{tabular}{|c|c|c|}
\hline Family & Genera & Species \\
\hline \multirow{18}{*}{ Pezizaceae } & \multirow{15}{*}{ Terfezia sp. } & Terfezia albida \\
\hline & & Terfezia arenaria \\
\hline & & Terfezia boudieri \\
\hline & & Terfezia canariensis \\
\hline & & Terfezia claveryi \\
\hline & & Terfezia combonii \\
\hline & & Terfezia crack \\
\hline & & Terfezia eliocrocae \\
\hline & & Terfezia extremadurensis \\
\hline & & Terfezia fanfani \\
\hline & & Terfezia ledifolium \\
\hline & & Terfezia leptoderma \\
\hline & & Terfezia metaxasi \\
\hline & & Terfezia olbiensis \\
\hline & & Terfezia oligosperma \\
\hline & \multirow{3}{*}{ Tirmania sp. } & Tirmania africana \\
\hline & & Tirmania nivea \\
\hline & & Tirmania pinoyi \\
\hline \multirow{9}{*}{ Tuberaceae } & \multirow{7}{*}{ Tuber sp. } & Tuber aestivum \\
\hline & & Tuber asa \\
\hline & & Tuber brumale \\
\hline & & Tuber indicum \\
\hline & & Tuber melanosporum \\
\hline & & Tuber micheli \\
\hline & & Tuber nitidum \\
\hline & Picoa sp. & $\begin{array}{l}\text { Picoa juniperi } \\
\text { Picoa lefebvrei }\end{array}$ \\
\hline & Phaeangium sp & Phaeangium lefebvrei \\
\hline
\end{tabular}

\section{Chemical composition and nutritional value}

Although desert truffles are consumed mainly for tradition and for their pleasant taste, they have significant amounts of proteins and very high amounts of antioxidants (phenols), which make them important in terms of nutritional value [3]. The following Table 2 is a summary of some studies about the nutritional value of some species of desert truffles, including moisture, proteins, carbohydrates, fat, crude fiber, and ash contents. Terfezia boudieri (Pezizaceae) is used both for food and for traditional medicine [36]; it has traditional uses (for food and aphrodisiacs) and the eating quality is excellent [17]. Desert truffles are rich in antioxidants and could be used as a food supplement [37]. Terfezia boudieri is rich in carbohydrates, proteins, fat, fibers, ash, and total phenolic content, and poor in energy (about 34 - 65 $\mathrm{kcal} / 100 \mathrm{~g}$ ). Terfezia $\mathrm{sp}$. has a magnesium element of $182.3 \mathrm{mg} / 100 \mathrm{~g}$, based on the dried truffle. Also, it has a vitamin $\mathrm{C}$ content of less than $1 \mathrm{~g} / 100 \mathrm{~g}$ (based on the dry weight). Thus, T. boudieri can be used as an important natural food [38] and as a source for natural health products [36].

The chemical composition and nutritional quality of Iraqi truffles, Terfezia boudieri, Terfezia claveryi, and Tirmania nivea are a good source of about 18 essential amino acids, like glycine, alanine, phenyl alanine, arginine, aspartic acid, glutamic acid, histidine, cystine, methionine, threonine, serine, lysine, isoleucine, leucine, proline, tyrosine, valine, and tryptophan. On the other hand, desert truffles are rich in both saturated and unsaturated fatty acids. Terfezia boudieri is rich in fatty acids such as pentadecanoic, margaric, stearic, arachidic [39], behenic, palmitic, palmitoleic, stearic, oleic, linoleic, and 
http://wjst.wu.ac.th

linolenic acids [40]. Tirmania nivea contains palmitic acid, stearic acid, oleic acid, and linoleic acid. Tirmania pinoyi contains fatty acids such as myristic, margaric, stearic, nonadecanoic, arachidic, heneicosanoic, behanic, euric, palmitoleic, oleic, and linolenic acids [39].

Ascorbic acid (vitamin C) level in Tirmania nivea is about $1-1.8 \mathrm{mg} / 100 \mathrm{~g}$, Terfezia claveryi 1.8 - 2 $\mathrm{mg} / 100 \mathrm{~g}$, and Terfezia boudieri 4.8 - $4.9 \mathrm{mg} / 100 \mathrm{~g}$ [11], and these species contain the following elements: $\mathrm{N}, \mathrm{P}, \mathrm{K}, \mathrm{Ca}, \mathrm{Mg}, \mathrm{Na}, \mathrm{Fe}, \mathrm{Mn}, \mathrm{Cu}$, and $\mathrm{Zn}$, dependent on the truffle species [41]. T. boudieri contains flavonoids such as myricetin, kaempferol, naringenin (not found in most mushrooms), and resveratrol [40]. The free ergosterol content of Tuber sp. ranges from 1.28 to $1.80 \mathrm{mg} / \mathrm{g}$, and the total phenolic compounds (o-coumaric and $p$-coumaric acids) varies from 1.20 to $1.88 \mathrm{mg} / \mathrm{g}$ of dried matter [42]. This truffle also has phenolic compounds such as gallic acid, homogentisic acid, protocatechuic acid, $p$ hydroxybenzoic, 3,4-dihydroxybenzaldehyde, $p$-coumaric acid, $o$-coumaric acid, hydroxybenzoic acid, and hydroxycinnamic acid [42].

Table 2 Chemical composition of desert truffle Terfezia sp. (g/100g based on the dried matter).

\begin{tabular}{lccccccc}
\hline \multicolumn{1}{c}{ Truffles } & Moisture & Carbohydrates & Protein & Fat & Ash & Fibers & References \\
\hline Terfezia boudieri & 75.4 & ND & 25.1 & 4.3 & 6.1 & 11.3 & {$[11]$} \\
Terfezia boudieri & 76.1 & ND & 24.7 & 4.6 & 6.3 & 12.6 & {$[11]$} \\
Terfezia boudieri & 10.25 & ND & 20.13 & 3.45 & 7.8 & ND & {$[40]$} \\
Terfezia boudieri & $80-90$ & $4.8-11.6$ & $1.4-2.7$ & $0.8-1.7$ & $1.0-1.9$ & ND & {$[43]$} \\
Terfezia claveryi & 74.9 & ND & 23.0 & 3.1 & 5.2 & 9.8 & {$[11]$} \\
Terfezia claveryi & 75.2 & ND & 23.0 & 3.5 & 4.6 & 8.0 & {$[11]$} \\
Terfezia claveryi & ND & ND & 15.95 & 6.95 & 4.25 & ND & {$[44]$} \\
Terfezia claveryi & ND & ND & 19.2 & 6.9 & & ND & {$[45]$} \\
Terfezia claveryi & ND & 16.7 & 8.0 & ND & 8.9 & ND & {$[46]$} \\
Terfezia claveryi & ND & ND & 19.6 & 4.7 & 4.5 & 7 & {$[47]$} \\
Terfezia sp. & $73-78$ & $11-17$ & $4-5$ & $0.6-1.8$ & $0.8-1$ & $1.4-2.6$ & {$[3]$} \\
Terfezia sp. & ND & 1.4 & 2.7 & 2.2 & 19.9 & ND & {$[41]$} \\
Tirmania nivea & ND & 21.5 & 13.8 & ND & 4.9 & ND & {$[46]$} \\
Tirmania nivea & ND & ND & 72.2 & 2.8 & 5.4 & 13.2 & {$[47]$} \\
Tirmania nivea & 70.0 & ND & 26.4 & 6.5 & 4.1 & 8.1 & {$[11]$} \\
Tirmania nivea & 73.5 & ND & 25.8 & 6.2 & 5.2 & 6.5 & {$[11]$} \\
Tirmania pinoyi & 82.3 & 82.59 & 8.1 & 4.1 & 5.2 & ND & {$[48]$} \\
Tirmania pinoyi & ND & 24.9 & 10.5 & ND & 5.6 & ND & {$[46]$} \\
Tirmania sp. & ND & 1.9 & 1.9 & 3.3 & 5.8 & ND & {$[41]$} \\
Picoa juniperi & ND & ND & 22.5 & 19.9 & 8.2 & ND & {$[44]$} \\
\hline
\end{tabular}

Legend: ND: not detected.

\section{Medicinal uses}

The medicinal value of desert truffles includes many biomedical applications (Table 3). Desert truffles have a very high amount of various antioxidants [3,38]. Moroccan truffles Tirmania nivea have antioxidant/antiradical activity [49]. Iraqi truffles (white and black) were found to inhibit the replication of Tomato Mosaic Virus [41].

$T$. claveryi and $T$. nivea can be used as a source of natural therapeutic agents in the treatment of eye infections which are caused by some resistant bacteria [8], such as the species Pseudomonas aeruginosa and the species Staphylococcus aureus [50]. Methanolic extracts of Terfezia boudieri have antioxidant and antiradical properties due to the high total phenols, total carotenoids, and anthocyanin contents; thus, it is used as a pharmaceutical agent [37]. Extracts of T. boudieri have antimicrobial activity against Gram negative and Gram positive bacteria and yeasts using a micro dilution method [38]. 
http://wjst.wu.ac.th

The antimicrobial activity of an aqueous extract of Terfezia claveryi aqueous extract inhibited about $66.4 \%$ against $S$. aureus, in vitro [51]. Acetone extracts of T. boudieri have excellent antimicrobial and antifungal activities against Streptococcus pyogenes, Bacillus subtilis, and Candida albicans [36]. Also, Terfezia sp. was found to be active against plant pathogenic fungi [52].

A methanolic extract of Tirmania pinoyi showed in vitro antioxidant and antimicrobial activities towards S. aureus [48]. Iraqi truffle (Terfezia sp. and Tirmania sp.) showed a high inhibitory activity in extracted tannins and glycosides against the growth of pathogenic bacteria such as Ps. aeruginosa, K. pneumonia, S. aureus, E. coli, Proteus sp., Enterobacter sp., and Aeromonas sp., and fungi such as Fusarium sp., A. nigar, and A. terrus [41], due to their phenolic compounds content [42]. Terfezia sp.and Tirmania sp. showed anticancer activity, immune-modulating activity, antiviral activity, hepatoprotective activity, and antidepressant activity [53,54]. Finally, desert truffles are important as a simultaneous food and drug, especially in the treatment of eye infections without side-effects [8].

Table 3 Biomedical application of desert truffles.

\begin{tabular}{|c|c|c|c|}
\hline Truffle name & Active compounds & Biomedical applications & References \\
\hline Terfezia sp. & Crude water extract & $\begin{array}{l}\text { Treatment of eye } \\
\text { infections }\end{array}$ & {$[8]$} \\
\hline Tirmania sp. & Crude water extract & $\begin{array}{l}\text { Treatment of eye } \\
\text { infections }\end{array}$ & {$[8]$} \\
\hline Terfezia boudieri & Acetone extract & $\begin{array}{l}\text { Antibacterial and } \\
\text { antifungal activities }\end{array}$ & {$[36]$} \\
\hline Terfezia boudieri & $\begin{array}{c}\text { Phenols, carotenoids, and } \\
\text { anthocyanin }\end{array}$ & $\begin{array}{c}\text { Antioxidant and } \\
\text { antiradical activities }\end{array}$ & {$[37]$} \\
\hline Terfezia boudieri & Crude extract & $\begin{array}{c}\text { Antibacterial and } \\
\text { anticandidal activities }\end{array}$ & {$[38]$} \\
\hline Terfezia boudieri & Flavonoid & $\begin{array}{c}\text { Radical scavenging } \\
\text { activity }\end{array}$ & {$[40]$} \\
\hline Tirmania sp. & Tannins and glycosides & $\begin{array}{l}\text { Antibacterial, antifungal, } \\
\text { and antiviral activities }\end{array}$ & {$[41]$} \\
\hline Terfezia $\mathrm{sp}$. & Tannins and glycosides & $\begin{array}{l}\text { Antibacterial, antifungal, } \\
\text { and antiviral activities }\end{array}$ & {$[41]$} \\
\hline Tuber aestivum & Ergosterol and phenolic & Antioxidant activity & {$[42]$} \\
\hline Tuber melanosporum & Ergosterol and phenolic & Antioxidant activity & [42] \\
\hline Tuber indicum & Ergosterol and phenolic & Antioxidant activity & [42] \\
\hline Tirmania pinoyi & $\begin{array}{l}\text { Tocopherol free sugars, } \\
\text { and fatty acids }\end{array}$ & $\begin{array}{c}\text { Antioxidant and } \\
\text { antibacterial activities }\end{array}$ & [48] \\
\hline Tirmania nivea & Phenols & $\begin{array}{l}\text { Antioxidant and } \\
\text { antiradical activities }\end{array}$ & [49] \\
\hline Terfezia claveryi & $\begin{array}{l}\text { Stigmasterol, } \beta \text {-sitosterol, } \\
\text { squalene, and lupeol }\end{array}$ & $\begin{array}{c}\text { Anticancer and } \\
\text { antioxidant activities }\end{array}$ & {$[53]$} \\
\hline $\begin{array}{l}\text { Terfezia sp. and } \\
\text { Tirmania } \mathrm{sp.}\end{array}$ & Varied & $\begin{array}{l}\text { Immune-modulating, } \\
\text { antiviral, hepato- } \\
\text { protective, and } \\
\text { antidepressant activities }\end{array}$ & {$[54]$} \\
\hline
\end{tabular}


http://wjst.wu.ac.th

\section{Conclusions}

In this review, desert truffles were identified using morphological and/or genetic characteristics. Terfezia sp. and Tirmania sp. are the most abundant truffles in Middle Eastern countries. Desert truffles grow naturally after rainfall during Al-Wasm in arid and semi-arid districts of Saudi Arabia, Iraq, Kuwait, Qatar, Bahrain, United Arab Emirates, Syria, Palestine, Lebanon, Jordan, Egypt, Iran, Turkey, Tunisia, Algeria, Libya, and Morocco. The number of truffle increases depending on the amount of rainfall, as in other countries. Desert truffles have nutritional value and immune-modulating, hepatoprotective, antidepressant, antibacterial, antifungal, antiviral, antioxidant, and antiradical properties, due to their phenol, carotenoid, anthocyanin, ascorbic acid, flavonoid, tannin, glycoside, and ergosterol content; thus, the introduction of desert truffles in the pharmacological field is important, especially for treating eye infections and cancer. Finally, the habitat of the truffles and the host-plants needs protection as nature reserves.

\section{References}

[1] P Iddison. Truffles in Middle Eastern Cookery. Emirates Natural History Group (Patron: H.E. Sheikh Nahayan bin Mubarak Al Nahayan), Available at: http://www.enhg.org/alain/phil/truffle/truffle.htm, accessed January 2016.

[2] R Splivallo, S Ottonello, A Mello and P Karlovsky. Truffle volatiles: From chemical ecology to aroma biosynthesis. New Phytol 2008; 189, 688-99.

[3] A Rodriguez. Desert Truffles. Trufamania, Available at: http://www.trufamania.com/deserttruffles.htm, accessed July 2016.

[4] MN Owaid. Biodiversity and bioecology of Iraqi desert truffles (Pezizaceae) during season 2014. $J$ Arid. Agr. 2016; 2, 22-5.

[5] A Ammarellou and H Saremi. Mycorrhiza between Kobresia bellardii (All.) Degel and Terfezia boudieri Chatin. Turk. J. Bot. 2008; 32, 17-23.

[6] S Jamali and Z Banihashemi. Nested-PCR for detecting Terfezia claveryi in roots of Helianthemum species in field and greenhouse conditions. J. Agr. Sci. Tech. 2013; 15, 377-87.

[7] A Slama, Z Fortas, A Boudabous and M Neffati. Cultivation of an edible desert truffle (Terfezia boudieri Chatin). Afr. J. Microbiol. Res. 2010; 4, 2350-6.

[8] ABNM Al-Rahmah. Desert and Forest Truffles, (Fuga) Food and Drug (in Arabic). $2^{\text {nd }}$ ed. Saud Kingdom University, Saudi Arabia, 2014, p. 1-288.

[9] HA Bokhary. Desert truffles 'AI-Kamah' of the Kingdom of Saudi Arabia 1. Occurrence, identification and distribution. Arab Gulf Sci. Res. Agr. Biol. Sci. B 1987; 5, 245-55.

[10] QA Mandeel and AA Al-Laith. Ethnomycological aspects of the desert truffle among native Bahraini and non-Bahraini peoples of the Kingdom of Bahrain. J. Ethnopharm. 2007; 110, 118-29.

[11] AA Al-Rawi and AM Taha. Chemical study for three Iraqi truffles types. Al-Anbar J. Agr. Sci. $2010 ; 8,33-41$.

[12] GM Kovacs, TK Balazs, FD Calonge and MP Martin. The diversity of Terfezia desert truffles: New species and a highly variable species complex with intrasporocarpic nrDNA ITS heterogeneity. Mycologia 2011; 103, 841-53.

[13] A Ammarellou, H Saremi and F Gucin. Evaluation of morphology, cytology and mycorrhizal relationships of desert truffles (Terfezia boudieri) in Iran. Pak. J. Biol. Sci. 2007; 10, 1486-90.

[14] A Mello, C Murat and P Bonfante. Truffles: Much more than a prized and local fungal delicacy. FEMS Microbiol. Lett. 2006; 260, 1-8.

[15] HA Bokhary, S Parvez and AM Shibl. Some spoilage microflora of desert truffles 'AI-Kamah' of The Kingdom of Saudi Arabia. J. Food Protec. 1990; 53, 779-81.

[16] AH Abuzinada, ER Robinson, IH Nader and YI Al-Wetaid. First Saudi Arabian National Report on the Convention on Biological Diversity. The National Commission for Wildlife Conservation and Development, Saudi Arabia, 2008, p. 131. 
http://wjst.wu.ac.th

[17] M Akyuz, S Kirbag and M Kursat. Ecological aspects of the arid and semi-arid truffle in Turkey: Evaluation of soil characteristics, morphology, distribution, and mycorrhizal relationships. Turk. $J$. Bot. 2012; 36, 386-91.

[18] E Shavit. The History of Desert Truffle Use. In: V Kagan-Zur, N Roth-Bejerano, Y Sitrit and A Morte (eds.). Desert Truffles, Phylogeny, Physiology, Distribution and Domestication, SpringerVerlag Berlin Heidelberg, 2014.

[19] AM Alsheikh. 1994, Taxonomy and Mycorrhizal Ecology of the Desert Truffles in the Genus Terfezia. Ph.D. Thesis, Oregon State University, Corvallis, USA.

[20] S Jamali and Z Banihashemi. Hosts and distribution of desert truffles in Iran, based on morphological and molecular criteria. J. Agr. Sci. Tech. 2012; 14, 1379-96.

[21] I Sbissi, F Ghodhbane-Gtari, M Neffati, H Ouzari, A Boudabous and M Gtari. Diversity of the desert truffle Terfezia boudieri Chatin. in southern Tunisia. Can. J. Microbiol. 2011; 57, 599-605.

[22] L Bradai, S Bissati and H Chenchuni. Desert truffles of the North Algerian Sahara: Diversity and bioecology. Emir. J. Food Agr. 2014; 26, 425-35.

[23] L Bradai, S Bissati, H Chenchouni and K Amrani. Effects of climate on the productivity of desert truffles beneath hyper-arid conditions. Int. J. Biometeorol. 2015; 59, 907-15.

[24] A Navarro-Rodenas, MC Lozano-Carrillo, M Perez-Gilabert and A Morte. Effect of water stress on in vitro mycelium cultures of two mycorrhizal desert truffles. Mycorrhiza 2011; 21, 247-53.

[25] M Akyuz, S Kirbag, B Bircan and Y Gurhan. Diversity and distribution of arid-semi arid truffle (Terfezia and Picoa) in Elazig-Malatya region of Turkey. Mycosphere 2015; 6, 766-83.

[26] HA Bokhary and S Parvez. Soil mycoflora from truffle native areas of Saudi Arabia. Mycopathologia 1992; 118, 103-7.

[27] HA Bokhary and S Parvez. Soil mycoflora from wild desert truffle habitats in northern Saudi Arabia. J. Arid. Environ. 1992; 23, 379-88.

[28] A Navarro-Rodenas, G Barzana, E Nicolas, A Carra, A Schubert and A Morte. Expression analysis of aquaporins from desert truffle mycorrhizal symbiosis reveals a fine-tuned regulation under drought. Mol. Plant Microbe Interact. 2013; 26, 1068-78.

[29] A Navarro-Rodenas, A Morte and M Perez-Gilabert. Partial purification, characterisation and histochemical localisation of alkaline phosphatase from ascocarps of the edible desert truffle Terfezia claveryi Chatin. Plant Biol. (Stuttg) 2009; 11, 678-85.

[30] JM Lopez-Nicolas, M Perez-Gilabert, F Garcia-Carmona, MC Lozano-Carrillo and A Morte. Mycelium growth stimulation of the desert truffle Terfezia claveryi Chatin by $\beta$-cyclodextrin. Biotechnol. Prog. 2013; 29, 1558-64.

[31] T Laessoe and K Hansen. Truffle trouble: what happened to the Tuberales? Mycol. Res. 2007; 111, 1075-99.

[32] GS Barseghyan and SP Wasser. Species diversity of hypogeous ascomycetes in Israel. Mycobiology $2010 ; 38,159-65$.

[33] GM Kovacs, JM Trappe, AM Alsheikh, K Hansen, RA Healy and P Vagi. Terfezia disappears from the American truffle mycota as two new genera and Mattirolomyces species emerge. Mycologia $2011 ; 103,831-40$.

[34] G Chevalier. The European Desert Truffles. In: V Kagan-Zur, N Roth-Bejerano, Y Sitrit and A Morte (eds.).Desert Truffles, Phylogeny, Physiology, Distribution and Domestication. SpringerVerlag Berlin Heidelberg, 2014, p. 121-41.

[35] J Diez, JL Manjon, F Martin. Molecular phylogeny of the mycorrhizal desert truffles (Terfezia and Tirmania), host specificity and edaphic tolerance. Mycologia 2002; 94, 247-59.

[36] HH Dogan, R Duman, B Ozkalp and S Aydin. Antimicrobial activities of some mushrooms in Turkey. Pharm. Biol. 2013; 51, 707-11.

[37] H Gouzi, M Leboukh and E Bouchouka. Antioxidant and antiradical properties of methanolic extracts from Algerian wild edible desert truffles (Terfezia and Tirmania, Ascomycetes). Int. J. Med. Mushrooms 2013; 15, 471-86.

[38] HH Dogan and S Aydin. Determination of antimicrobial effect, antioxidant activity and phenolic contents of desert truffle in Turkey. Afr. J. Tradit. Compl. Altern. Med. 2013; 10, 52-8. 
http://wjst.wu.ac.th

[39] HA Bokhary, AAA Suleiman and MO Basalah. The fatty acid components of the desert truffle 'AI Kamah' of Saudi Arabia. J. Food Protect. 1989; 52, 668-9.

[40] M Akyuz. Nutritive value, flavonoid content and radical scavenging activity of the truffle (Terfezia boudieri Chatin). J. Soil Sci. Plant Nutr. 2013; 13, 143-51.

[41] WAA Al-Mahamdi. 2011, Study the Biological Activity of Some Iraq Truffle Extracts Tuber (Rutba Region) Against Microorganisms and Tomato Mosaic Virus. M.Sc. Thesis, College of Science, University of Anbar, Iraq.

[42] A Villares, A Garcia-Lafuente, E Guillamon and A Ramos. Identification and quantification of ergosterol and phenolic compounds occurring in Tuber spp. truffles. J. Food Comp. Anal. 2012; 26, 177-82.

[43] A Dundar, YO Faruk, H Acay, V Okumus, S Ozdemir and A Yildiz. Antioxidant properties, chemical composition and nutritional value of Terfezia boudieri (Chatin) from Turkey. J. Food Sci. Tech. Int. 2012; 18, 317-28.

[44] MA Murcia, M Martinez-Tome, AM Vera, A Morte, A Gutierrez, M Honrubia and AM Jimenez. Effect of industrial processing on desert truffles (Terfezia claveryi Chatin and Picoa juniperi Vittadini): proximate composition and fatty acids. J. Sci. Food Agr. 2003; 83, 535-41.

[45] MT Kaisey, HA Hadwan, HA Abeed, EJ Taher and BL Dhar. Proximate analysis of Iraqi truffles. Mush. Res. 1996; 5, 105-8.

[46] N Al-Naama, M Ewaze and JO Nema. Chemical constituents of Iraqi truffles. Iraq J. Agr. Sci. $1988 ; 6,51-6$.

[47] WN Sawaya, A Al-Shalhat, A Al-Sogair and M Al-Mohammad. Chemical composition and nutritive value of truffle of Saudi Arabia. J. Food Sci. 2006; 50, 450-3.

[48] D Stojkovic, FS Reis, ICFR. Ferreira, L Barros, J Glamoclija, A Ciric, M Nikolic, T Stevic, A Giveli and M Sokovic. Tirmania pinoyi: Chemical composition, in vitro antioxidant and antibacterial activities and in situ control of Staphylococcus aureus in chicken soup. Food Res. Int. 2013; 53, 56-62.

[49] A Ameer and A AL-Laith. Antioxidant components and antioxidant/antiradical activities of desert truffle (Tirmania nivea) from various Middle Eastern origins. J. Food Comp. Anal. 2010; 23, 15-22.

[50] H Gouzi, L Belyagoubi, KN Abdelali and A Khelifi. In vitro antibacterial activities of aqueous extracts from Algerian desert truffles (Terfezia and Tirmania, Ascomycetes) against Pseudomonas aeruginosa and Staphylococcus aureus. Int. J. Med. Mush. 2011; 13, 553-8.

[51] S Janakat, S Al-Fakhiri and AK Sallal. A promising peptide antibiotic from Terfezia claveryi aqueous extract against Staphylococcus aureus in vitro. Phytother. Res. 2004; 18, 810-3.

[52] NC Paul, WK Kim, SK Woo, MS Park and SH Yu. Diversity of endophytic fungi associated with Taraxacum coreanum and their antifungal activity. Mycobiology 2008; 34, 185-90.

[53] SS Dahham, SS Al-Rawi, AH Ibrahim, ASA Majid and AMSA Majid. Antioxidant, anticancer, apoptosis properties and chemical composition of black truffle Terfezia claveryi. Saudi J. Biol. Sci. 2017, DOI: 10.1016/j.sjbs.2016.01.031.

[54] M Gajos, F Ryszka and J Geistlinger. The therapeutic potential of truffle fungi: A patent survey. Acta Mycol. 2014; 49, 305-18. 